\title{
French Labor Relations: A Functional Analysis
}

The French system of labor relations, like so many things French, is quite distinctive. It would be barely comprehensible to the American worker in its de-emphasis on collective bargaining, its multiplicity of union divisions and alliances, and its reliance on labor courts to settle individual grievances. French unions are weak in terms of members and strike funds; until recently dues collection within the plant had been prohibited; the closed shop is illegal. Collective agreements are rarely concluded at the plant level; and regional accords meeting certain statutory requirements may be extended by government decree to cover an entire industry, including parties who did not participate in the negotiations.

In view of such striking differences, the French system seems worthy of more comprehensive analysis than it has thus far received. Moreover, a wave of recent innovations stemming from the unrest of 1968 may suggest additional points of comparison between the French and American systems. This Note will attempt to provide a general description of the French system, assessing its strengths and weaknesses. It will then recast that description in terms of the framework of functional analysis-a mode of perception which may suggest a different way in which to view industrial relations, both foreign and domestic.

\section{The French Labor Relations System}

\section{A. The Participants}

The Unions. There has long been a disparity between the theory and reality of French union structure. ${ }^{1}$ In theory, power is decentralized, with the local, the basic unit, closely controlled by its members. In reality, however, local independence and membership control are weak. Power resides principally in regional organizations, which cut across industries and are pivotal in bargaining and strikes. ${ }^{2}$ Officials of these organizations, which comprise all the locals of one

1. For a statement of this theory, and an assertion of this disparity almost twenty years ago, see V. Lorwin, The French LABor Movement 146 (1954) [hereinafter citcd as LORWIN].

2. For example, the G.G.T. metals unions form the powerful Metal Workers Council of the Paris Region. 
confederation in a given region, typically represent the union on public regulatory, mediation, and advisory agencies; they assist locals in organization, strikes, and negotiations.

The three major confederations-the Communist dominated Confédération Générale du Travail (C.G.T.); the Christian trade movement's descendant, the Confédération Française Démocratique du Travail (C.F.D.T.); and the predominantly white-collar Confédération Générale des Cadres (G.G.G.) ${ }^{3}$-are formally responsible for determining national policy and for dealing with the national government. But they are often out of touch with their constituent units, the regional organizations and unions, and today, as two decades ago, "Government, whether of state or trade unions still inspires distrust." However, the confederations have recently emphasized the need for contact with workers, spontaneous action by constituent organizations, and priority for rank-and-file grievances, ${ }^{5}$ and this may suggest some improvement in the level of communications between the rank-andfile and national labor leaders.

Employers. By all accounts, the managers of France's great corporations constitute as unrepentant a group of nineteenth century industrial barons as remain in the West. Resenting the very presence of unions in the plant, these managers would rather see reforms imposed by the government than by concessions to labor demands.

The employer federation, the Conseil National du Patronat Français (G.N.P.F.), unites management into a group more cohesive than

3. Among workers, the C.G.T. received about forty-five percent of the vote for $\mathrm{cm}$ ployee representatives; the C.F.D.T., twenty percent; the C.G.C., five percent, with the remainder split among splinter and unaffiliated unions. Blanc-Jouvan, The Settlement of Labor Disputes in France, in Labor Courts aNd GRIEvance Setruenent is WestenN Europe 5 (B. Aaron ed. 1971) [hereinafter cited as Blanc-Jouvan]. Yet it has been estimated that all French unions still organize only fifteen to twenty pereent of all cligible workers. H. Ehranans, Polrtics in France 173 (1968) [hercinafter cited as Eunuasis, Polmics]; H. LESIRE-OGREL, LE sYNDICAT DANS L'ENTREPRISE 128 (1967) [hercinafter cited as LESIRE-OGREL].

4. LoRwis, supra note 1, at 164. For example, when C.G.T. Secretary-General Seguy returned from negotiations at the height of the 1968 strikes and presented his gains to the rank and file at a huge Renault plant, twelve thousand workers booed him. The C.G.T. leadership scurried back to the bargaining table. N.Y. Times, May 28, 1968, at 8 , col. 1 .

5. The current attitudes of the two major unions may be summarized as follows: In the wake of the 1968 outburst, the C.G.T. has emphasized the need for contact with the masses and for labor unity. As a consequence, it has given priority to rank-and-file grievances. It has refused no-strike pledges which would block renegotiation as pressure develops from below and expressed a preference for action by stalute rather than by contract, in order to achieve relative stability with a minimum of commitunent.

The C.F.D.T. has been even more open to spontaneous worker action. The unions' objectives include worker control, democratic planning, and improvement in the quality of worker life. See Reynaud, Dassa, Dassa \& Maclouf, Les évenements de mai et juin 1968 et le système français de relations professionelles, [1971] Sociolocie du Travalt 73, 191, 192-205, 208 [hereinafter cited as Reynaud]. 
the unions. The federation, embracing approximately 900,000 concerns employing over six million workers, ${ }^{0}$ has substantial influence on the content of collective bargaining through the staff it provides its affiliates. Still, some institutional barriers are evident: The permanent staff of the employer organization is isolated from its constituents; employer ideology decrees enterprise autonomy, with the association intervening only on problems of an industry or regional nature; liaison officers to the association hold ambiguous positions in their firm's chain of command. ${ }^{7}$

Management even views government planning as an additional mechanism for its control. Indeed,

in some ways, the development of French planning in the 1950s can be viewed as an act of voluntary collusion between senior civil servants and the senior managers of big business. ${ }^{8}$

The State. The French government plays a far greater role in determining the conditions of employment than do American labor agencies. Minimum wages, vacations, hours, and other aspects of work are set by law. ${ }^{9}$ Conciliation of most collective disputes is mandatory, ${ }^{10}$ and mediation may be invoked by the government in major disputes. ${ }^{11}$ The state also plays a major role in collective bargaining ranging from periodic discussions over minimum wages to incessant prodding by agencies such as the "Ministère de Commerce" on the details of collective agreements. ${ }^{12}$

\section{B. Labor Relations in the Plant}

With the government as their apparent ally, the managers of French industry exercise a degree of dominance that would appall most American labor leaders. By law, the employer is given the power to promulgate règlement intérieur, regulations which govern daily life in the plant. ${ }^{13}$ Unions have only recently won legal recognition of their right

6. S. Holt, Six European States 67 (1970).

7. Reynaud, supra note 5, at 88-89.

8. A. Shonfield, Modern Capitalism 120 (1969).

9. Legislation regulates hiring practices, family allowances, and health insurancc. Un. employment insurance is provided for in collective agreements negotiated at the nat tional level and often extended by government decree. F. MEYErs, THE STATE AND GoverNMENT EMployees UNions in France 6-7 (1971).

10. If conciliation procedures are not provided in the collective agrcement, the dis. pute goes to a tripartite commission where the public member plays the pivotal role.

11. Blanc-Jouvan, supra note 3 , at 52,59 .

12. Sellier, L'évolution des négociations collectives dans la sidérurgie et la métallurgic en France (1950-1969), [1970] DroIT Socias 431, 447.

13. Lesire-OGrer, supra note 3, at 69-70; C. Trav. Liv. I, art. 22a (30e ed. Petits Codes Dalloz 1959). 
to organize at the plant level, and the extent of this and other essential union powers remains vaguely defined. Finally, the primary mechanism for consultation by workers, the plant committee, is largely ineffective.

In composing plant regulations, the employer must submit his proposals to the plant committee and the government's Labor Inspector. The former, however, is limited to suggesting changes and the latter to retracting or modifying provisions which are contrary to statute. As a result, the regulations routinely contain clauses of great breadth such as prohibitions on "all activity alien to this firm," or "all political or philosophical discussion." 14 With such discretion, management exercises near-complete control over discipline.15 By the use of "temporary suspensions," employers commonly use such prohibitions to circumvent the spirit of the Labor Code, which ostensibly limits disciplinary fines to certain offenses and to one-fourth of the worker's wage. ${ }^{16}$

As a result of the 1968 unrest, the employers have been forced to yield-on paper-some of their power. ${ }^{17}$ In 1969, for example, the C.N.P.F. and all the representative unions reached an agreement on employment security which provided for consultation with workers through their plant committees in the event of mass lay-offs. The agreement stipulates priorities in rehiring and requires firms to reclassify or retrain any workers laid off. Another national agreement in 1970 placed workers on a monthly salary basis, guaranteeing a measure of job security and fringe benefits formerly limited to white collar workers. ${ }^{18}$

The real effect of these developments, however, remains to be seen. The individual French worker is still often at the mercy of his employer. In the past, employees have been legally discharged for smoking in the washstand, taking a forty-five minute rest after eleven hours of work, or having union magazines in their lockers. If the employee is

14. LeSIRE-OGREL, supta note 3, at 71 .

15. Id. at 72. The disciplinary power of management is nowhere found in the Code and actually rests on judge-made law. In a 1945 decision, the Cour de Cassation (the principal appellate court) stated:

The employer disposes of a disciplinary power inherent in his character and which,

in the absence of limiting internal rules, he may use subject only to judicial review. Id. at 73 .

16. Id. at 75; C. Trav. Liv. I, art. 22b (30e ed. Petits Codes Dallor 1959).

17. See Le mouvement syndical et le bilan social de la "nouvelle societé," 80 REve D'Econonie Polmuve 936 (1970); Camerlynck, Le bilan de l'annice 1969 en droit du travail français, 25 Relations INDustrienles 369; N.Y. Times, Oct. 24, 1969, at 2, col. 4; id., Mar. 22, 1970, at 41, col. 5; id., July 11, 1970, at 3, col. 5.

18. N.Y. Times, May 2, 1970, at 41 , col. 5 . 
temporarily suspended-another favorite management tactic-the employer's decision will be reversed only if the worker is able to prove that the employer's purpose was purely to injure the worker and that it was not in the interest of the enterprise. Even if the court overturns the discharge or suspension, the worker will receive damages only if he can show that the dismissal was abusif: that the motive for dismissal was anti-union, a violation of contract, or the product of procedural failures. ${ }^{19}$

Courts have played some part in entrenching management's dominance by interpreting restrictively recent legislative efforts to redress the balance. For example, the Cour de Cassation has held that advisory commissions on discipline established by collective contract and authorized by statute were not meant to deal with layoffs. ${ }^{20}$ Similarly, though the law of 1950 provided that a strike does not create a breach of contract (except in the case of "major fault")," the courts have permitted firms to hire strike-breakers and then refuse to rehire strikers. Indeed, the primary difficulty with legislative reforms has been that the judges interpret each section of the Labor Code in the light of their conservative notions of the civil law, rather than viewing the entire Code as a comprehensive law for the protection of workers.22

But the most important reason for the comparative weakness of French unions is their ambiguous status under the law. Until 1969, unions had no right to organize and collect dues within the plant or to appoint plant delegates with the power to sign collective agreements. Management had no obligation to permit union organizing or to deal with union representatives, and by and large, it refused to do either. ${ }^{23}$ The 1969 reforms, while establishing the principle of plant organization, imposed significant limitations-which American workers would almost certainly regard as crippling-on the exercise of that right.

The second article of the 1969 law, for example, limits the right to establish a local to "representative" unions recognized by the government at the national level. It thus precludes protection of many locals

19. Lesire-OGRe, supra note 3, at 93-100. There is language in the Code du Travail (C. Trav. Liv. I, art. 23 (30e ed. Petits Codes Dalloz 1959)) which indicates that a judge could require the employer to provide his motive for discharge, but the courts have either refused to require justification or have accepted very broad excuses. Thus, the Cour de Cassation reversed a judgment ordering further inquiry where the justification given was that the worker was "professionally unsatisfactory." [1968] Bull. Civ. IV 40.

20. LESIRE-OGREI, supra note 3, at 98; [1965] Bull. Civ. IV 782.

21. Id.

22. Id. at 99-100.

23. A. Sturmthal, Workers Council 47.49 (1964) [hereinafter cited as Sturmthal]. 
which sprang into being in the wake of the 1968 strike and which are not formal units of such nationally recognized unions. Furthermore, due to its size limitation (to firms with fifty or more employees), the new statute does not apply to one-third of all industrial workers and three-fourths of all those engaged in commerce; the law also excludes all public enterprise. Although it permits dues collection in the plant, it does not apply specifically to the place or time of work; it limits the right to distribute literature to that which is "professional" in nature. ${ }^{24}$

The 1969 reforms, moreover, failed to address the coercive practices applied by employers to inhibit unionization-practices which persist despite the formal recognition of union rights. Employers have handicapped locals' elections, for example, by restricting the posting of announcements. ${ }^{25}$ They have placed union leaders in jobs which isolate them from fellow workers, and have often refused to meet regularly with leaders who enjoy genuine worker support. Firing union organizers, even in the face of government opposition, is still a common ploy. ${ }^{20}$

The institutions and individuals responsible for representing worker interests and grievances on a day-to-day basis are also unable to redress management's dominance. A number of representatives-shop stewards, union delegates, plant committee members-play some formal role. It has been argued that the impotence of these representatives may be due to the splintering of authority among them. But a more realistic explanation may be that employers have refused to concede any authority to any of them. ${ }^{27}$

Plant committees, which are required in every firm with more than fifty employees, are composed of both workers and managers, and must include at least one member nominated by the unions. If plants

24. Statute of Dec. 27, 1968, [1968] J.O. 12403. See also de La Gressaje, La présence du syndicat dans lentreprise, [1969] 3 Drort Social 153, 155.56.

25. At the Ivry plant in 1966, five posters were used to announce elections for a firm employing 7,000 workers.

26. For example, in April 1965 management-imposed layoffs at a television manufacturing concern precipitated a union drive. The C.G.T., F.O., and C.F.D.T. all demanded elections. The company refused and fired nine organizers. The Inspector tried to mediate, and an appeal was taken. A meeting took place under the auspices of the director of manpower; although the company threatened to close if its actions vicre not upheld, the Inspector refused to sustain the company. The company made good its threat to shut down.

27. Hélène Sinay, for example, argues that this multiplicity of vorker representatives is not objectionable, since the functions they perform are different. She sees the only true overlap between the stewards and union delegates in the area of grievance handling. It may be argued, however, that the 1968 statute is an invitation 10 future bickering and labor movement weakness. Sinay, Le degré d'intensite de la présence syndicale dans l'entreprise, [1969] DrorT Social 454. 
complied (and workers sought compliance) with the law, there would be 23,000 such committees in France. Yet at last count, Le Monde reported that only 6,000 exist, and that only about fifty percent were operating well. ${ }^{28}$ In theory, the committees must be consulted by management on matters of organization, administration, layoffs, plant regulations, and vacations. They must be informed regarding profits and losses and may make suggestions as to profit, product, or price changes. In fact, however, plant committees rarely exercise any influence in matters outside the area of medical and social services. ${ }^{20}$ Most do not even concern themselves with operational matters. Employers often categorically refuse consultation on wages and ignore suggestions on plant regulations. ${ }^{30}$ The usual employer tactic is to consult post facto as to economic matters or to swamp the committees with trivia, thus taking advantage of the workers' lack of expertise.

Shop stewards and union delegates similarly offer little more than the shadow of representation. Although both play a role in collecting dues, distributing literature, and holding union meetings, they differ from each other in one important respect: The former are elected by workers, while the latter are appointed by union officials outside the firm. Neither has authority to achieve resolution of employee grievances that are binding on employers. Workers thus often prefer to pursue remedies through other channels, ${ }^{31}$ and the use of stewards for handling grievances has declined. Finally, since stewards often face employer discrimination, the post is not a very popular one. ${ }^{32}$

Specialization of leaders' roles in these positions tends to widen the gap between the rank and file and their leadership. Different individuals present grievances as personnel delegates, deal with management as members of the plant committees, and negotiate as union

28. Le Monde, Feb. 11, 1970, at 1, col. 1 .

29. Such services include insurance, the canteen, vacation homes, kindergartens, hos. pitals, clubs, and relief funds.

30. STURMthal, supra note 23 , at $39-40$.

31. Primarily the labor courts. See pp. 818.19; SruRmthat, supra note 23, at 31.

32. Id. at 32. Theoretically, any dismissal of a personnel delegate must be cleared with the plant committee, and its objection can be overriden only with the approval of the Labor Inspector. The same procedure was extended by later statites to members of the plant committee, former members, candidates, and union representatives. But the courts have distorted these statutes, holding that they may review the decision of the Inspector but that damages may not be awarded until the litigation, including all ap. peals, is completed. [1952] $\mathrm{D}$. Jur. 290 (Cass. civ. soc. 21 Feb. 1952); see Lesike-OGkEL, supra note 3 , at 102-03. By such time, the worker may be long unemployed. Morcover, even when an employee successfully appeals an adverse decision of the Inspector, reinstatement will not be granted. Thus, even if the employer loses at every level, he need not rehirc. He can always fire a committee or union member if he is willing to pay damages which rarely exceed four months salary. [1964] D. Jur. 578 (Cass. civ. soc. I July 1964); sce LESIRE-OGREL, supra, at 104 . 
leaders. Consequently, the ties between the three roles are weak, and grievances raised in the plant committees rarely result in collective contract provisions.

\section{Collective Bargaining}

The structure and custom of collective bargaining in France also enhance employer power. The right of unions to negotiate and the "duty to bargain" have never been legally recognized, either by the courts or by statute. Reforms since 1969 have altered the system in some respects-resulting, for example, in collective contracts which for the first time link wage increases to the cost of living. But there is no certainty that such innovations will become a national trend. Indeed, it would be surprising if certain deeply-ingrained and widelyaccepted practices cease to prevail.

French labor contracts typically shun the detailed content of a full collective agreement and thus grant management considerable discretion in determining the greater part of wages through bonuses. Most agreements concern only wages and benefits and there they set only minima which employers may increase. Such discretion is clearly in accord with the French theory of enterprise autonomy. Although unions have criticized the system, ${ }^{33}$ stipulations as to bonuses are rarely incorporated in collective contracts. ${ }^{34}$ Recent accords tying wage increases to the cost of living-for example, in the electricity and gas industries ${ }^{35}-$ may, however, ultimately produce some restrictions on the employer's power. But unions were compelled to make concessions of their own in return for this gain-agreeing not to reopen the issue of wages during a two-year period. Hence, even in the long run, such provisions may not alter the balance of power.

Management dominates the collective bargaining process itself in a more basic sense through its ability to choose its opponent-that is, the bargaining unit with which it will deal. Very little bargaining occurs at the plant level and virtually none in concerns with more than one plant. Instead, the usual pattern is for several unions to bargain simultaneously with many employers (represented by a single employer association) at the level of a locality or region. Although the determination of the bargaining unit is left to the parties, typically

33. F. Sellier, Stratege de la Lutte Soclale 167 (1961) [hercinafter cited as Seluer, STRATEGRE].

34. 1d. at 173 .

35. Camerlynck, Le bilan de l'année 1969 en droit du travail franģais, 25 Relutioss INDUSTRIELLES 369 (1969). 
the decision of the employer is controlling. ${ }^{30}$ Since these accords set only minima, additional terms may be negotiated in the individual's contract, so that a worker may be simultaneously covered by a broad regional accord, a national pact on special matters, and informal plant level agreements. When two or more agreements overlap, simultaneous application has been held permissible, ${ }^{37}$ with the result that workers at a lower level cannot waive gains obtained regionally or nationally. ${ }^{38}$

Management typically pushes most critical bargaining to the regional level, which is most advantageous to it. ${ }^{30}$ At the local level, there is the fearsome prospect of "workers' control." At the national level, its union adversaries are likely to be more expert. In 1955 the nationalized Renault Corporation did conclude a detailed plant-level agreement on every aspect of employment. ${ }^{40}$ But few firms have followed Renault's experiment. By forcing negotiations at a regional level, management gives the unions the worst of both worlds: Labor has neither the competence of the higher levels, nor the rank-andfile support of the plant. Bargaining at the regional level tends to undercut union cohesiveness and enhance the myriad fissures that plague labor-fissures between union leaders and rank and file, between wage earners and salaried workers, and among various skill categories. ${ }^{41}$ At the regional level, workers in the advanced sectors are likely to be disadvantaged since negotiations typically gravitate toward a lowest common denominator including the unskilled.

Apart from the government sessions, management need not bargain with all representative unions, or only with representative unions. The upshot is a continually shifting pattern of multi-union bargaining. ${ }^{42}$

36. LoRwiN, supra note 1 , at $190-97$.

37. M. Despax, Conventions Collectives, 7 Traite de Droit du Trayail 305 (G. Camerlynck ed. 1966).

38. LoRwIN, supra note 1 , at 213.

39. Sellier, Strategie, supra note 33 , at 187.

40. The Renault accords, hailed as a turning point in French labor relations, contained provisions regarding exhaustion of conciliation before resort to strikes or lock. outs, a commitment by management to a four percent wage increase during each of the following two years, and provisions for holidays, sickness, and retirement. $A$ cost-of living committee was established to attempt to maintain purchasing power, though final decisions were left with management. $I d$. at 197-98.

The no-strike pledges were suspect among unions. The experiment was looked upon with favor by management, who thought the new accords would lessen turnover and provide labor peace. However, small and medium sized firms were antagonistic, fearing that the concessions made in the new agreements would be generalized and extended.

41. On the regional level, the difficulty of attaining unity among the several unions prevents labor from taking the initiative for a settlement. Management recognizes the union's weaknesses and turns to mediation only when local firms secm too ready to yield to union pressure. Id. at 178.85 .

42. LoRwin, supra note 1 , at 205-08. 
However, if a collective agreement is signed by one union but rejected by another, it nevertheless applies to all the workers including members of the union which refused. ${ }^{43}$ Finally, since no-strike clauses are not employed, unions may still strike during the term of contract, whether or not they signed it. ${ }^{44}$

The role of the government in the collective bargaining process is an important one. Indirectly, as a major employer itself, it sets a pattern for private bargains. It may intervene directly to shape the outcome of private negotiation by providing subsidies that permit increased wage settlements. ${ }^{45}$ It has the power to "extend" agreements, at the request of any representative union or employer group or the Minister of Labor, so that the contract between a particular union and management groups becomes binding on the entire industry with quasi-statutory effect. ${ }^{46}$ With complete discretion, it may convene conciliation or bargaining sessions to settle major disputes. ${ }^{47}$ It gives unions the right to participate in those sessions by recognizing them as "representative." Finally, through its substantial planning and control authority over the economy in general, the government exercises immense power over the real effect of any agreement reached privately. In 1970, labor won a long-sought reform in the level of the minimum wage-linking it to the average wage level throughout the country. ${ }^{48}$ Formerly, the minimum wage tended to determine the average level-rather than vice versa-since contract negotiations throughout the country typically awaited and reacted to the minimum level set by the government after consultation with labor and management

43. Savatier, French Report, 18 RuTGERs L. REv. 375, 386 (1964).

44. F. MEYERS, supra note 9, at 5-6.

45. In the metal industry a variety of factors, including union action and strikes, helped bring about real negotiations and agreement. Economic difficulties on the part of business and state intervention were pivotal factors. But the critial factor in exerting pressure for agreement was the government's promise of a subsidy in the cvent of vage increase.

46. From 1945 to 1965 of 202 contracts concluded at the national level, fifty-six vere extended; of 143 regional accords, twenty-two extended; of 382 local agreements, cighteen extended. Despax, Conventions Colmectives, supra note 37 , at 360 .

The obligatory content of extended contracts has been one obstacle to wider application. The Minister of Labor has apparently avoided full use of extension out of concern for marginal firms.

47. When parties have not provided by contract for conciliation, they must resort to government panels. Moreover, the role of the state in the ongoing process of bargaining is manifest. For example, Frangois Sellier reports that the Ilinistry of Social Affairs encouraged a steel industry agreement in the $1960^{\circ}$ 's concerning sick pay' realizing that such an accord would take pressure off the state's compensation system. Sellier, L'évolution des négociations collectives dans la sidérugie et la métallurgie en France (1950. 1969), [1970] 9 Drorr Social 431, 433.

48. Camerlynck, Le bilan de l'année 1970 en droit du travail français, 26 RELarnosis INDUSTRIELIES $490,491(1970)$. 
representatives. ${ }^{49}$ But the 1970 measure has scarcely diluted the government's power in this area. Paris continues to compute the "average" level, thereby presumably setting the mark for the next round of regional and local negotiations.

Thus, the French worker's wages, hours, and conditions of employment are determined in large part by forces beyond his controlby a bargaining process dominated by his employer, by a government with sweeping economic powers, and by independent economic trends. As one commentator has summarized the situation:

In France the real income of the wage earning group as a whole, even in the short run, is determined more by price changes and the incidence of indirect taxation than by money wage readjustments. . . Bargaining on money wages is to a great extent a form of political and economic competition among different groups within the working class. ${ }^{50}$

\section{Settling Grievances}

Once contracts are concluded, disputes over their validity, interpretation, and execution are assigned to four primary mechanisms: conciliation, mediation, arbitration, and the labor courts. The first three deal with collective disputes while labor courts settle individual ones between an employer and his employees. Since the former have been largely ineffective, many collective disputes have been defined as "individual," so as to bring them within the labor courts' jurisdiction. These courts have the advantages of speed, economy, expertise, and informality. Still, they may grant only limited remedies, so that surmounting the individual/collective fiction is only a limited solution. Moreover, reliance on such courts has reduced the unions' role in grievance settlement to insignificance.

By law, parties must submit disputes to a conciliation commission, whether or not such a step is contractually mandated. The commissions are statutory, tripartite bodies-with the government member playing a decisive role as president-which exist at the departmental, regional, and national level. Conciliation failure is common, since there is little incentive to agree. Other mechanisms such as the courts are then available, ${ }^{51}$ and the parties may engage in a strike or lockout while conciliation is in process. Thus, the statutory mechanism is

49. LoRwiN, supra note 1 , at 222-23.

50. Id. at 219.

51. Blanc-Jouvan, supra note 3 , at 49 . 
little more than a pressurized form of collective bargaining. Of some 1800 disputes submitted to conciliation between 1950 and 1967, 427 succeeded, 120 partly succeeded and 1,252 failed. 52

A conciliation attempt is not, however, a prerequisite to invoking the second mechanism, mediation, involving intervention of a third party. ${ }^{53}$ If one party desires mediation, he may petition the president of a conciliation commission; if the petition is granted, the adversary must join. Moreover, the Minister of Labor can initiate mediation even if neither party seeks it. Mediation, however, has not proven much more effective than conciliation. Although the Minister of Labor may publish the mediator's recommendation in order to exert pressure on the parties, the recommendation is not binding. The mechanism is now used only in cases large enough to justify the use of prestigious mediators, who may bring to bear the force of their extraordinary expertise or reputation. ${ }^{54}$

Arbitration, the third mechanism, is rarely used. It is not compulsory in France by law and is rarely stipulated by contract. One reason for this fact is that while the procedure is voluntarily instituted, any award is binding. ${ }^{55}$ Another major reason why it is employed only a few times a year ${ }^{56}$ is the difficulty in agreeing on the arbitrator. Contractual arbitration clauses normally specify only a procedure and arbitrator, who may be a single person or a panel. Both parties tend to dislike the discretion allowed arbitrators, out of fear that their collective agreement will be overridden. Unions particularly resist such clauses because they are less tightly organized at the plant level, where arbitration would occur and are reluctant to relinquish the strike weapon to obtain arbitration promises. ${ }^{57}$ More fundamentally, private arbitration seems contrary to the French tradition of state intervention and judicial decree.

Because arbitration of individual employee grievances is rare in France, ${ }^{58}$ the major burden of settling such disputes falls on the fourth

52. Id. at 54 .

53. Decree of May 5, 1955, [1955] J.O. 4493; amended by Decree of June 11, 1955, [1955] J.O. 5923; Statute of July 26, 1957, [1957] J.0. 7459; Decree of July 18, 1958, [1958] J.0. 6801 .

54. Blanc-Jouvan, supra note 3 , at 59 .

55. Id. at 61, n.41; Statute of Feb. 11, 1950, [1950] J.O. 1688, as amended Statute of July 26, 1957 [1957] J.O. 7459.

56. Blanc-Jouvan, supra note 3 , at $62-68$.

57. Under the 1936-39 system, where compulsory arbitration was cffective, the government was socialist, the unions strong, and the employers unorganized. Today the situation is reversed. Id. at 69-70, 77.

58. W. McPherson \& F. Meyers, The French Labor Courts: Judgsievt ax Peers (1966) [hereinafter cited as MCPHERson \& MEYERS]. 
mechanism, the labor courts. ${ }^{50}$ These are permanent, semi-judicial bodies created by decree and composed of equal numbers of management and union representatives. ${ }^{60}$ Reliance on them exemplifies the common belief pervading much of French labor relations that all employees are entitled to the same minimum protection, and that the responsibility for providing such protection lies with the state. The unions' minor role in grievance settlement is thus limited to tasks such as the screening of complaints.

The limitation of the courts' jurisdiction to "individual" disputesthose involving one employer and one employee ${ }^{01}$-derives from the theory that the courts should be restricted to grievances arising from the individual employment contract. ${ }^{02}$ However, the Cour de Cassation has held that several individuals with similar claims do not trans. form an individual dispute into a collective one; rather they constitute merely a series of individual disputes. ${ }^{63}$ Reacting to the ineffectiveness of the mechanisms for resolving collective disputes, many lower courts have exploited this theory to enlarge their jurisdiction, ${ }^{04}$ often allowing the parties' characterization to control. ${ }^{\circ 5}$ The express terms of the individual contract of employment are commonly only the starting point for their examination, since under French law that contract sweeps in the requirements of statutes, the collective contract, oral or written agreements, and even custom. ${ }^{\mathbf{B b}}$

The first step in consideration by the labor court is compulsory conciliation by a panel of one employee and one employer judge. If conciliation is successful, the agreement is incorporated in a "procès verbal de conciliation" which is enforceable just as any other judg-

59. Blanc-Jouvan, supra note 3 , at 19.

60. Each labor court is established by a decree, and may have scctions covering four areas: industry (blue collar), commerce (white collar), agriculture, and miscellancous. Decree of Dec. 22, 1958, [1958] J.O. 11621. If a labor court has no section for a particular type of action, those cases go to the ordinary local court. "Cadres" (white collar and managerial personnel) have the option of resorting to the ordinary courts in any case. McPHerson \& MeYers at 22.

In 1965, there were over two hundred labor courts throughont France; yet it is esti. mated that one-third of all individual labor disputes cannot come before a labor court due to either a lack of any court in the vicinity or of one with an appropriate scction. Blanc-Jouvan, supra note 3 , at 19.

61. Blanc-Jouvan, supra note 3 , at 9-11.

62. Id.; MicPherson \& Meyers, supra note 58, at 24.

63. [1951] Gazette du Palais II 261 (Cass. civ. soc. 21 June 1951). By contrast a col. lective dispute turns on the rights or interests of a group of workers. The group may or may not be a union; it may be a local group or a national one; and it may be opposed by one or several employers. Blanc-Jouvan, supra notc 3, at 10.

64. [1960] D. Jur. 401 (Cass. civ. soc. 3 Feb. 1960).

65. [1960] D. Jur. 688 (Cass. civ. soc. 23 June 1960). See also Blanc-Jouvan, supra note 3 , at 11 .

66. MCPHERson \& Meyers, supra note 58, at 24; Blanc-Jouvan, supra note 8, at 6; Despax, Conventions Collectives, supra note 37 , at 76-77. 
ment. Since conciliation rarely succeeds-indeed, success in conciliation has declined over the past twenty years-most cases go to a judgment session. ${ }^{67}$ This session entails a hearing before two employer and two employee judges. Some commentators have noted that often the whole process is used by the employer to delay compensation or merely for spite. ${ }^{68}$

Still, the court's record is relatively impressive: In all, final decision is reached in some thirty-five to forty percent of the cases, some 20,000 per year. The bipartite nature of the courts apparently does not spur bitter partisanship, and the interest of the lay judges in maintaining their neutral position precludes deadlocks which would require the intervention of a government judge.

Nonetheless, the protection afforded workers by the courts has been criticised as "illusory" 69 because of strict limitations on the remedies they may grant. As is generally true under French law, ${ }^{70}$ the court can grant only damages-and not specific performance-when a party fails to execute a contract. Thus the labor court cannot order the reinstatement of a discharged worker: Most workers are consequently reluctant to resort to the courts prior to termination, and the labor court mechanism often has the effect merely of reducing the unions' role without providing effective remedies. In short, its stress on individual grievances and the discouragement of collective action furthers management's ability to divide and conquer.

\section{E. Strikes, Lockouts, Street Conflict}

The ultimate weapon of French workers is direct action-the strike, plant occupation, sequestration of management, and the ultimatum. French law, however, is not always hospitable to such tactics. The constitution of 1946 guaranteed the right to strike "within the framework of the laws which regulate it," ${ }^{11}$ and the constitution of 1958 incorporates this provision by reference. ${ }^{72}$ But the courts have limited the right by excluding certain actions from the definition of strike and by considering others under penal provisions prohibiting "interference with the free exercise of industry and work." ${ }^{\text {"73 }}$

67. Blanc-Jouvan, supra note 3, at 30-33; C. Trav. Lrv. IV, art. 57, 67a (30e cd. Petits Codes Dalloz 1959).

68. MCPherson \& MeYers, supra note 58, at 41 .

69. Blanc-Jouvan, supra note 3 , at 36 .

70. Id. at 34 .

71. Preamble to Constitution of 1946, [1946] J.O. 9166.

72. Preamble to Constitution of 1958, [1958] J.0. 9151.

73. Kanowitz, The Strike and Lockout Under French Labor Law, 9 ST. Lou1s L.J. 211, 213-15 (1964). C. PEN. art. 414-15 (56e ed. Petits Codes Dalloz 1959). 
Political strikes and lockouts are not protected. According to certain judicial decisions, an economic action must attain a sufficient level of participation to be a protected strike. In the case of a strike which attracts only a portion of the work force, an employer must continue to provide work for those who remain unless the strike is of such magnitude as to amount to force majeure. But "rotating strikes," where there is a planned sharing of picketing, and slowdowns are not pro. tected, and the employer may lockout without notice. Paradoxically, occupation of a plant, though subject to criminal sanctions, does not breach the contract for purposes of reemployment. ${ }^{74}$ Finally, the unilateral lockout receives different judicial treatment than does the strike. The employer need only resort to conciliation before he engages in unilateral lockout.

For much of their history, French unions "viewed the conclusion of a mutually binding collective agreement as inadmissible class collaboration." "75 As a result, the strike has been used more as a warning to management that it must rectify some objectionable situation than as a means of reaching agreement. This absence of a clear relationship between strikes and negotiations has accentuated the role of the state. Indeed, the primary aim of the strike is often to provoke state intervention. Major emphasis is therefore placed on solidarity demonstrations and public disruptions which will produce political gainsgains thought to be proportionately greater than those achieved through parliamentary action. ${ }^{70}$ The events of May 1968 were the most dramatic manifestation of such power, but it was present in the violence both before and after those chaotic days. ${ }^{77}$

74. The 1950 collective bargaining law stipulates that a strike, instead of destroying the employment contract, merely suspends it. This suggests that striking workers must be rehired. But French courts have held that it is not breach of contract on the part of the employer to refuse to rehire a worker if the employer has hired a replacement during the course of the strike: the refusal to rehire is approved on the basis of the obligation to the new worker. [1952] D. Jur. 706 (Cass civ. soc. 24 July 1952). But cf. H. Sinay, La Greve, 6 Traite de Droit du Travail 218 (G. Camerlynck cd. 1966) for the proposition that this case is an aberration, and generally, the statute is followed.

75. MEYers, supra note 9, at 24.

76. See Sellier, Strategie, supra note 33, at 299-309.

77. In 1969 strikes spread throughout France on the cve of Parliamentary debate on the economy. There were marches in dozens of cities; in Paris, government offices werc occupied for hours; Lyons was paralyzed by purposely stalled automobiles; clashes with police erupted. N.Y. Times, Sept. 16, 1969, at 3, col. 5. At the Batignolles plant in Nantes in 1971 workers ransacked the plant, destroyed files, and threw typewriters out windows. Id., Jan. 28, 1971, at 4, col. 5. And in January 1972, a strike at the shipyards of Brest was accompanied by sequestration of management. Le Monde, Jan. 26, 1972, at 23, col. 1. Clearly, group, class, ideological, and generational antagonisms were not obliterated by the Gaullist electoral victories. See also EurmanN, PoLrrics, supra note 8, at 332-43. 
II. Functional Analysis of the System

An application of functional analysis shifts our approach from an examination of the system institution by institution, to an analysis of the tasks performed by that system. Instead of a mere static description, it can provide a more systematic method for selecting strategies for change. The framework to be used here is that developed in Comparative Politics by Gabriel Almond and G. Bingham Powell. ${ }^{78}$ While Almond and Powell suggest that a political system may be analyzed in several different respects, two seem particularly relevant-the system's conversion process and its resulting capabilities. ${ }^{79}$

The conversion process has to do with the internal functioning of a system: The way in which demands are formulated (interest articulation) and combined into alternative courses of action (interest aggregation); and the manner in which the rules which govern the actors in the system-of both public law and private agreement-are formulated (rule making), applied (rule application), and enforced (adjudication). ${ }^{30}$

Capability analysis evaluates how well the system as a whole performs. Almond and Powell assess such performance'by five tests: the extractive, distributive, symbolic, regulative, and responsive capabilities. ${ }^{81}$ The extractive involves obtaining resources from one member of the system so that they may be transferred to another. The distributive pertains to the allocation of goods, services, and opportunities among both individuals and groups. The symbolic involves the availability of symbols which tap popular beliefs, attitudes, and aspirations so as to maintain the legitimacy of the system. The regulative refers to the exercise of control over the membership. Finally, responsiveness is judged in terms of how the system reacts: to whom, in what areas of activity, and by what mechanisms.

\section{A. The Labor Relations System as Part of the Entire Political System}

Functional analysis can first provide us with an evaluation of the labor relations system as a part of the larger political system of France. The role of industrial relations in enhancing the extractive and distributive capabilities of the entire political system, though undoubted-

78. G. Almond \& G. Poivell, Comparative Polmtes (1960) [hereinafter cited as Alarond \& Powell]. For a similar approach more familiar to lawjers and legal scholars see Lasswell \& McDougal, Criteria for a Theory about Law, 44 U.S.C.L. REv. 362, 387 (1971); The Identification and Appraisal of Diverse Systems of Public Order, 53 Axs. J. INT. L. 1, 9, 17 (1959) .

79. AlmoNd \& Power. 28, 73-212.

80. Id. at 29.

81. Id. at 190-203. 
ly important, is largely a matter of labor economics beyond the scope of this Note. By way of summary, we should note Lorwin's comment that the labor sub-system has not-as its social theory would suggestproduced a redistribution of wealth from the managerial to the working class. Rather,

increased benefits have come, not out of profits, but essentially out of a redistribution of income within the working class, as between direct wage and social wage recipients .... "The working class functions as a vast mutual aid association in which ... the poor help out the poorer." 82

The contribution of French labor relations to the symbolic capability of the political system seems to have been largely a negative one. The extremes of Marxist ideology and of Social Darwinism have produced antagonisms which make it difficult to compromise social differences.

Though the regulative capability of the political system is substantially supported by the French administrative bureaucracy, it is doubtful that the system of labor relations adds much to this capability. Private labor accords are infrequent and rarely fill gaps in legislation; collective disputes often lead to economic force.

A more elusive question, however, is the degree to which the labor relations system contributes to the responsiveness of the French political system. Some authorities have suggested that the political system lacks both responsiveness and authority. ${ }^{84}$ And the labor sub-system often seems unable to aid in this respect by resolving conflict among its antagonistic groups.

Yet on closer examination, the labor relations system's contribution in terms of responsiveness appears more complex. It might be argued that a high level of conflict is the price paid for the protection of individual rights and the opportunity for interest group activity. While it is true that the weakness of the labor movement is partially caused by multi-union bargaining, competition among unions may also be viewed as a means of protecting the individual worker from the arbitrary power of union monopolies. Similarly, there are two views of the importance of the government in labor relations. In one, the system is a vast company-union run by the state. But in another, this reliance on government decreases the dependence of the worker on his union, allows him to utilize alternatives such as plant committees

82. LoRwin, supra note 1 , af 227 .

83. See Ehrmann, Pourtics, supra note 3, at 131-42.

84. S. Beer \& A. Ulam, Patterns of Government 278 (1962). 
and labor courts and keeps the unions honest. The French pattern may thus shed some light-not altogether favorably-on the American labor scene with its union monopolies and oligarchic control.

\section{B. The Conversion Process of French Labor Relations}

Just as functional analysis aids us in appreciating the labor system's contribution to the overall political system, so we can now use it to explain why the labor relations system behaves as it does.

\section{Interest Articulation}

Opportunity for interest articulation appears widely diffused in the French labor system. In expressing complaints, the individual worker has a choice among several unions and among a variety of worker representatives or government officials. ${ }^{85}$

But there are two aspects of interest articulation which reveal real weakness. At the level of group articulation, available communication channels often seem inadequate, as indicated by the lack of consultation with labor on matters of economic planning and, at the private bargaining level, refusals by management to negotiate with a union it disfavors. ${ }^{86}$ This pattern seems to result from the multiplicity of organizations articulating labor's views. ${ }^{87}$ The impression of extensive interest articulation must be qualified, secondly, to take account of the significant gap between the rank and file and its leadership.

\section{Interest Aggregation}

Aggregating interests in the French labor system is a difficult task. On labor's side, internal differences may be suppressed by a powerful leadership. The resulting unified front may contribute to the regulative capability, but simultaneously preclude a responsiveness to divergent interests. On the other hand, where the leadership cannot maintain member support, labor is fatally weakened. Because of this frequent failure to achieve solidarity, regulation is often undertaken by legislation or the initiative of employers.

Conflicting interests within the labor movement are, of course, also found in the American system. But here, by a process of internal bargaining, unions usually achieve a united front. In France, a number

85. See pp. 811-12 supra.

86. See pp. 810, 812, 814 supra.

87. See pp. 807, 811, 814 supra. 
of factors inhibit such aggregation. Critical among these-as illustrated in 1968 and discussed above-is lack of rank-and-file support. In almost all enterprises, labor contact with the masses is restricted by specialization of leaders' roles, failure to consult rank and file, and anti-union judicial constructions and employer activity. ${ }^{88}$ At levels higher than the enterprise, interest aggregation is inhibited by union competition. With little to offer their followers, the unions are forced to stress ideological distinctions-thus making compromise within the movement even more difficult.

The possibility that these failures can ultimately be traced to French attitudes toward bargaining and organizational authority is supported by the fact that employers sometimes seem to have as much difficulty as labor during a crisis. During 1968, for example, the employer associations seemed as paralyzed and incapable of effective action as the unions. The resistance to common action, deference to decision makers, and other aspects of organization seem deeply rooted in the behavior of all sides in the labor relations system.

\section{Rule Making}

The true failure of the labor relations system is manifest in the process of rule making, where the system performs badly or not at all. Rules prescribed in other countries by collective bargaining are either ordained by statute or left to the discretion of the management. ${ }^{80}$ Beyond this relative de-emphasis on private ordering, it also appears that rule making, to the extent that it occurs at all, contributes instability to the system's regulative capability. The inclination to negotiate at higher levels makes it difficult to adjust to local conditions. Moreover, the procedures of collective bargaining themselves encourage delay: Since few contracts terminate at a specified time and there is no duty to bargain, delays accumulate and eventually the situation becomes a crisis involving a resort to economic force. ${ }^{00}$ Thus, just as the failings of aggregation often mean that labor lacks the power necessary to obtain responsiveness without provoking disorder, so at the rule making stage, the nature of the procedures provokes further disruption.

\section{Rule Application}

Unlike the other stages of the conversion process, it is difficult to generalize about rule application. Of course, the state is involved in

88. See pp. 810, 819 supra.

89. See p. 813 supra.

90. See p. 820 supra. 
many areas, but, as noted above, certain firms at times have flouted statutory requirements. On other matters of internal plant operation, rule application is left to management or is shared with the plant committee. ${ }^{91}$

Though the facts of daily administration of statutes and contracts are not clearly known, the deficiencies of the adjudicative function indicate that application is rather sporadic. Accords may be one-sided or lack means of enforcement. Even where the staff of an employer association conscientiously seeks to monitor application, it may face employers demanding firm autonomy. Unions retain their suspicion of collective contracts, and are therefore reluctant to agree to no-strike clauses.

\section{Rule Adjudication}

Effective rule adjudication in French labor relations is not consistently available, due to the lack of an effective arbitration and mediation law. This is the principal reason that unions' interest shifts from private rule making to protest action designed to invoke the powers of the state.

As far as responsiveness is concerned, the absence of mechanisms for the settlement of collective disputes adds to the system's inability to adjust to a variety of situations. It is difficult to determine the degree to which this is modified by the sub rosa use of the labor courts to adjudicate collective disputes. But when confined to individual disputes, the responsiveness of the adjudicative mechanism is doubtful. The labor courts, while providing a remedial mechanism for nonunion as well as union members, 92 are precluded from offering the allimportant remedy of reinstatement.

In thus summarizing the functioning of French labor relations, the system's problems and peculiarities emerge rather clearly. Poor performance in interest aggregation, rule making, and adjudication, lead to periodic direct and disruptive labor actions aimed more at the public and the state than at individual employers. Labor's difficulty in aggregating interests promotes crisis as a means of mobilizing adherents. Finally, in rule making and adjudication, the lack of institutions which contribute significantly to the resolution of collective disputes again forces labor to rely on the state.

91. See pp. $809-10$.

92. MCPherson \& MEYers, supra note 58, at 9. Blane-Jouvan, The Statules of the Unorganized Workets, in DISPUTE SETtLeMENT IN FIVE WESTERN EURoreaN Coustrues 35-38 (B. Aaron ed. 1969). 
Though somewhat more difficult to evaluate, the contribution of the labor system to the responsive capability of the political system does not seem to be significant: The weakness of labor means that both systems are less responsive to the workers than they might be. Moreover, the tendencies which produce a politics of "crisis liquidation" result in a responsiveness which is too blunt to satisfy anyone. During crisis, business and government are hurt by social conflict; during calm, labor watches impotently as its hard-won gains are circum. vented and construed out of existence.

\section{Law and the Strategies of Change}

It was suggested that one virtue of functional analysis is that it may lead to a strategy for change which does not deal with institutions at random, but rather treats the system as a whole. In light of the above descriptions and categorizations, we may now suggest such a strategy.

While structural, economic, ${ }^{03}$ and cultural ${ }^{94}$ factors all undoubtedly

93. In 1962, Professor Arthur Ross suggested that traditional Europcan labor rclations were changing due to the affluence of the post-World War II period. He argued that the traditional systems were adapted to "decades marked by subsistence wages, frequent spells of severe unemployment, and extreme bitterness between the classes." Ross, Pros. perity and Labor Relations in Western Europe: Italy and France, 16 IND. \& LAt. REt. REV. 63, 64 (1962). In such times there was little hope for collective bargaining, and therefore no need to avoid ideological conflict on that account; on the political level where most action was focused, such conflict was useful in mobilizing support. Ross argued that the situation should change with the coming of full employment, rapid growth, tight labor markets, and advances in real earnings. Id. at 63.

Ross' analysis is helpful in understanding certain aspects of the system, such as the process by which the lessening of economic pressure contributed to ideological splintering and confilict among unions. However, as Ross acknowledged, the system cannot be ex. plained without considering noneconomic factors such as C.G.T. insistence on the ideology of class warfare, C.F.D.T. emphasis on centralized bargaining, management, in. transigence, and the crisis of Algeria which politicized all issues. Id. at 80.84. Morcover, while some union decentralization is at last occurring, the worker strength at the plant level posited by Ross' theory is not as clearly developing. See Delamottc, Recent Collectitic Bargaining Trends in France, 103 INT. LABOR REv. 351,372 (1971). Finally, cven whilc the "traditional" economic conditions existed, there were a number of sectors ci French industry, such as textiles, with relatively congenial labor-management relations. Thic explanation for this cooperation seems to be that there were serious splits among ent. ployers and a congruance of interests between labor and one important employer group. Sellier, Strategie, supra nole 33, at 317-29.

Apart from the need for greater specificity in economic hypotheses, there are other areas where economics fails us. For example, Ross suggested that increasing afflucuce would soften ideological divisions and class antagonisms. Yet a study by Richard Hamil. ton found that increasing radicalism does not correlate with economic deprivation and dissatisfaction. R. HAMILTON, AFFLUENCE AND THE FRENCH WORKER 275.78 (1967). Rather union organization seemed critical and there was a close correlation betwecn worker radicalism and the size of the firm.

94. Many social scientists who have examined the political culture of France have presented a picture of ineffective government, deeply divided classes, religious sectarian. ism, and a generally apathetic or "anti-civic" polity. See, e.g., Almond \& PowEl.t, supra note 78 , at $320-21$; EhrmanN, supra note 3 , at 309.12. Clearly, the ideological style and 
interact to produce the patterns of French labor relations, it is possible to single out particular factors as dominant in certain areas. For example, the slow shift in labor's strategy from a defensive to offensive one seems most likely linked to economics: Instead of relying solely on building minima into legislation, some development of the contract tool and a rather dramatic emphasis on plant level organizing have been undertaken. In other areas, cultural factors seem to predominate. The failure of interest aggregation, rejection of bargaining, and suspicion of leadership, may all stem from cultural attitudes pervasive in French society. Structural factors, usually secondary, are occasionally quite important: For example, the nearly total failure of the mediation law may be laid to the absence of provisions for compulsory arbitration.

Developing a strategy of change thus involves identifying those aspects of the system which are true sources of weakness and which are also most amenable to change. In France, these relate principally to interest aggregation. Yet French legislators, instead of focusing on interest aggregation, intervened at the stage of rule making and rule application by passing the 1955 mediation law. The law has been virtually a dead letter. The weakness of the unions which required them to retain the weapon of mass action made them resistant to binding arbitration. ${ }^{95}$ In short, the mediation law collided with the resistance to interest aggregation, rooted deeply in economic, cultural, and structural factors.

As a first priority target, interest aggregation must be further analyzed, however, to determine appropriate tactics for reform. For example, it might be possible to move toward single representative unions more on the American model. But more likely, given current worker attitudes, this would only result in a sharp increase in wildcat strikes. By contrast, reforming the law on dismissals so as to compel employers to give valid reasons for such actions would not cut against such ingrained worker attitudes. Such a move might thus decrease the violence of strikes and increase the ability of unions to hold their membership. In addition, it might be possible to reform the channels by which labor obtains access to state planning agencies; end the frag-

the failure of bargaining which inhibit interest aggregation and rule-making may reflect a pervasive pattern of the political culture. The absence of informal grierance proce. dures leading to the accumulation of unresolved disputes may result from a general dislike of face-to-face relationships, as may the centralized nature of the entire bargaining process. Similarly, suspicion toward authority makes it difficult for the unions to maintain sustained mass support. In short, many of the characteristics of the labor system conducive to union weakness, to an absence of low-level dispute settlement, and to the consequential instability of the system as a whole, secm rooted in the politial culture.

95. Seliner, Strategie, supra note 33, at 178-79. 
mentation among plant committee, personnel representative, and union representative; and provide the labor courts with the power of reinstatement. Only if the unions are treated fairly and are then still unable to attract adherents, should it be necessary to admit that a weak labor movement is the price French workers are willing to pay for individualism.

Having identified the stage of labor relations which is most amenable to change and having considered the tactics most likely to succeed, one final step remains: to consider the long-term economic and cultural forces which will handicap efforts to achieve short-term change and which must be modified if long-term goals are to be accomplished. For example, while the possible legal changes suggested above may increase the capacity for interest aggregation, union efforts will continue to confront deeply held social attitudes about bargaining and compromise. These in turn are affected by institutions throughout the society. Thus, the reformer must consider recommending change in the educational system, the bureaucracy, and other institutions which perpetuate class hierarchy and an anti-civic instinct.

All of this is but an outline of the kind of thought which should guide a strategy of reform. Undoubtedly, something like it already goes on in the minds of all astute politicians or lawyers. What has been suggested here is simply a more systematic approach. Hopefully such an examination may suggest some insights to American observers. For example, the consequences of overcentralization in the French system may cause us to think twice about establishing even an advisory pay board. We should also consider whether there is something about monopoly unions that quashes worker rights and about pluralist systems which makes for labor impotence. Finally, in areas akin to labor relations, such as race relations, the focus on factors such as interest aggregation may in this country be as important as in France. But while such insights may prove useful, the real purpose of this Note has been to suggest that the student of labor law-foreign or domestic -can profit from a systematic application of social science to the varied patterns of industrial relations. 